Received 01.11.2017 Reviewed 04.01 .2018 Accepted 18.01.2018

A - study design

B - data collection

C - statistical analysis

D - data interpretation

$\mathbf{E}$ - manuscript preparation

F - literature search

\section{Adoption of sawah eco-technology in rice production by farm households in Kebbi State, Nigeria}

\author{
Cornelius I. ALARIMA ${ }^{\text {ABDEF } ₫}$, Joseph M. AWOTUNDE ${ }^{\text {ACDE }}$, \\ Comfort O. ADAMU ACDE, Dare AKERELE ${ }^{\text {BCDEF, }}$ \\ Tsugiyuki MASUNAGA ${ }^{\text {AE }}$, Toshiyuki WAKATSUKI ${ }^{\text {A }}$
}

Federal University of Agriculture, Abeokuta, 11001 Abeokuta, Nigeria; e-mail: corneliusalarima@yahoo.com, moriremubo1@yahoo.com, comlare2004@yahoo.com, akereledare@yahoo.co.uk,masunaga@life.shimane-u.ac.jp, wakatsuki@life.shimane-u.ac.jp

For citation: Alarima C.I., Awotunde J.M., Adamu C.O., Akerele D., Masunaga T., Wakatsuki T. 2018. Adoption of sawah eco-technology in rice production by farm households in Kebbi State, Nigeria. Journal of Water and Land Development. No. 37 p. 11-17. DOI: 10.2478/jwld-2018-0020.

\begin{abstract}
This study examined factors influencing the adoption of sawah technology in Kebbi State, Nigeria. Sawah refers to levelled rice field surrounded by banks with inlet and outlet for irrigation and drainage. Using pre-tested interview guide, data were collected from 300 sawah farmers in the study area. Data collected were analysed with both descriptive and inferential statistics using STATA package. The results showed that respondents were predominantly male, married and had no formal education. The mean age of was 48.13 years with mean household size of 14 persons; farm sizes ranged from 1-50 hectares with average of 4.70 ha, the mean yield was 6.88 $\mathrm{t} \cdot \mathrm{ha}^{-1}$. The results further showed that bond construction had $100 \%$ adoption, nursery $99 \%$, puddling $98 \%$, flooding $95 \%$, leveling and smoothening $94 \%$ and power tiller use $88 \%$ adoption. Adoption of sawah technology was influenced by socio economic characteristics which include sex, age, educational level, farm size, yield and income of the farmers. The study also showed that the attributes of sawah, production factors, information and extension and perception of respondent toward sawah technology influenced adoption. It is concluded that the sawah eco-technology is widely adopted by rice farmers in Kebbi State. The study therefore recommended that dissemination of sawah to other states in Nigeria need to consider factors that promote its adoption. Improvement of those factors that significantly affect adoption of sawah technology is also recommended.
\end{abstract}

Key words: adoption, factors, Kebbi State, Nigeria, sawah technology

\section{INTRODUCTION}

Rice remains a vital component of the Nigerian diet and its importation makes an important share of Nigerian agricultural imports [OGUNDELE, OKORUWA 2006]. Nigeria population is increasing at a faster rate and the consumption of rice has increased rapidly than domestic rice production, thereby increasing the net importation of rice. An average Nigerian consumes $24.8 \mathrm{~kg}$ of rice per year, representing 9 per cent of annual calorie intake [IRRI 2001]. Nigeria has experienced rapid growth in per capita rice consumption during the last three decades, from $5 \mathrm{~kg}$ in the $1960 \mathrm{~s}$ to $25 \mathrm{~kg}$ in the late 1990s [WARDA 2003] with a potential for increase in years to come. The consumption of traditional cereals, mainly sorghum and millet, has fallen by $12 \mathrm{~kg}$ per capita, and their share in cereals used as food dropped from $61 \%$ in the early 1970 s to $49 \%$ in the early $1990 \mathrm{~s}$. In contrast, the share of rice in cereals consumed grew from $15 \%$ to $26 \%$ over the 
same period [AKPOKODJE et al. 2002; OGUNDELE, OKORUWA 2006].

The average yield of upland and lowland rainfed rice in Nigeria is $1.8 \mathrm{t} \cdot \mathrm{ha}^{-1}$, while that of the irrigation system is $3.0 \mathrm{t} \cdot \mathrm{ha}^{-1}$ [PCU 2002]. This is very low when compared to $3.0 \mathrm{t} \cdot \mathrm{ha}^{-1}$ from upland and lowland systems and $7.0 \mathrm{t} \cdot \mathrm{ha}^{-1}$ from irrigation systems in Côte d'Ivoire and Senegal [OGUNDELE, OKORUWA 2006; WARDA, NISER 2001].

Poor water control, abiotic stresses (which include variable rainfall with drought and flooding occurring in the same season, iron, aluminium and manganese toxicity), biotic stresses (such as weeds, insect pests, diseases, rats and birds), inappropriate cultivation practices (broadcasting of seed which decreases the germination rate and make it difficult to maintain the proper spacing for planting) and lack of and/or poor bunding and levelling account for the low rice productivity [BALASUBRAMANIAN et al. 2007; BURI et al. 2000].

In order for domestically grown rice to compete with imported rice, improved productivity of the local rice becomes essential. This necessitated the introduction and integration of sawah eco-technology in rice production in Nigeria. Sawah refers to man-made improved rice fields with demarcated, levelled, bunded and puddled rice fields with water inlet and outlet. It is a form of irrigated production system with water sources from canals, pond and spring. According to FASHOLA et al. [2006], sawah system offers the best option for overcoming the constraints of rice production in Nigeria, namely poor soil fertility, poor water management and poor varieties. Sawah system utilizes the inland valleys which are reported to be high in fertility (eco-technology). With appropriate water management in inland valleys, fertility can be sustained to enhance local rice production [WAKATSUKI, BURI 2008].

In Nigeria, the sawah system was introduced through on-farm adaptive research in the two research sites of Gara and Gadza inland valleys, located in Bida, Nigeria in 1986 [HIROSE, WAKATSUKI 2002]. Sawah was introduced to Kebbi State in 2012 with 4 Fadama groups in Birni Kebbi, Argungu, Bagudu and Jega. These groups were supported with water pumps, power tiller, fertilizer, improved rice seeds and herbicides.

Adoption of improved agricultural technologies has become a critical avenue for increasing productivity in developing countries [Doss 2006]. Adoption is the mental process an individual passes through from first hearing about an innovation to final adoption [ROGERS 2003]. An important component of adoption decision process is the understanding of the processes leading to the adoption of new technologies by farmers. Adoption studies have consistently emphasized the importance of various farmers and farm characteristics in determining whether or not such technologies will be adopted. The decision of a farmer to adopt a technology is however complex and involved two mutually exclusive processes; the first involves making the decision to adopt the specific technology in the first place, while the second involves deciding on the level or intensity of use of the same technology [WORTMAN, KIRUNGU 1999]. Research has shown that a number of farm-household factors such as the age, education, and personal characteristics of the household head; the size, location and tenure status of the farm; the availability of cash or credit for farm investment and access to urban markets were associated with farmers' decision [ALARIMA et al. 2011; ROGERS 2003]. This study therefore aims at examining the factor influencing the adoption of sawah technology among farmers in Kebbi State, Nigeria. The result of this study will serve as a platform for dissemination of sawah technology to other states in order to achieve self-sufficiency in rice production in Nigeria. With its inherent potential in increasing rice production, there is the need to develop a better understanding of the conditions that encourage its sustained adoption. The specific objectives are to describe the socio economic characteristics of the farmers, determine the level of adoption of sawah technology and to identify the factors determine the adoption of sawah among the farmers.

\section{METHODS}

\section{STUDY AREA}

The study was carried out in Kebbi State. The State was created in 1991, out of the then Sokoto State. Located between latitude $10^{\circ} 8^{\prime} \mathrm{N}$ and $13^{\circ} 15^{\prime} \mathrm{N}$ and longitude $3^{\circ} 30^{\prime} \mathrm{E}$ and $6^{\circ} 02^{\prime} \mathrm{E}$, the state is bounded by Sokoto State, Zamfara State, Dosso Region in the Republic of Niger to the North and East, Niger State to the South, and Benin Republic to the West. It has a total land area of $36,129 \mathrm{~km}^{2}$. Kebbi State has an agriculturally viable environment since it is endowed with high soil fertility, vast farmlands and economically viable rivers sheltered by fine tropical climate [Wikipedia undated]. Owing to these factors, agriculture has remained the major source of revenue and indeed the backbone of the economy of the state. Major food crops in the area are millet, guinea corn, maize, cassava, potatoes, rice, beans, onions and vegetables, while cash crops including wheat, soya beans, ginger, sugarcane, groundnuts and tobacco are also produced in the state.

\section{SAMPLING AND DATA COLLECTION}

Data were collected from 300 purposefully selected sawah farmers in the study area. Data used in this study were collected in all the sawah sites in Kebbi State namely Argungu, Birnin Kebbi, Jega and Bagudu. The farmers were selected based on their participation in sawah rice production. A wellstructured interview guide was used to elicit information from the farmers. 


\section{DATA ANALYSIS}

Descriptive statistics were used to analyse the socio-economic characteristics of the farmers. Regression analysis was used to determine the relationships between adoption and predictor variables as specified in the equations below. Equation (1) specified relationship between adoption and socio-economic characteristics of the respondents while Equation (2) shows the relationship between adoption and predictor variables as identified by ROGERS [2003]:

$$
\begin{gathered}
A D O P=a+\beta S E X+\beta A G G+\beta E D D+\beta H H S I Z+ \\
+\beta F S Z+\beta Y E I L+\beta \text { YREXP }+\beta \text { INCM } \\
\begin{array}{c}
A D O P=a+\beta A T T R+\beta P E R C+\beta I N F O+ \\
+\beta P R O D+\beta P O L Y
\end{array}
\end{gathered}
$$

Detailed description of the variable acronyms is shown in Table 1.

\section{MEASUREMENTS}

\section{Adoption}

Adoption was measured at nominal level by listing all the components of sawah technology as shown in Table 1.

\section{Factors affecting adoption}

This was measured at nominal level by listing the factors affecting adoption as identified by ALARIMA et al. [2016] and RogERS [2003] as shown in Table 1. These include attributes of sawah technology, perceptions and values, production factors, access to information and extension services and policy/ institutional supports.

\section{RESULTS AND DISCUSSION}

\section{DESCRIPTIVE STATISTICS}

The result of the study showed that respondents were mostly males. This shows that male farmers dominated sawah farming in the study area. This may be due to the fact that sawah is energy demanding which may discourage female farmers from adopting the technology. Age of farmers ranged between 20 and 72 years with a mean of $48.13(S D=12.04)$. Majority of the farmers had no formal education. The mean household size is 14 . The advantage of the relatively large household size of the farmers is that the family members could serve as a viable source of farm labour.

The average farm size of the respondents is 6.02 ha $(S D=7.17)$. As reported by WILLIAMS et al. [1984], the larger the farm size in terms of acreage or labour requirements, the earlier the farmer tends to adopt new practices applicable to his farm enterprise. The mean yield was $6.88 \mathrm{t} \cdot \mathrm{ha}^{-1}$. This is better that the average yield of $3 \mathrm{t} \cdot \mathrm{ha}^{-1}$ from tradition system of rice production and is comparable to rice yield in Asia. The results showed that mean years of experience in rice production is 25.16 years $(S D=12.80)$.

Average annual income of farmers is $\$ 786,000$ $(2,043$ USD at the rate of $385=1$ USD). This shows that sawah farmers from the study area are above the poverty line of 2 USD per day.

\section{LEVEL OF ADOPTION OF SAWAH TECHNOLOGY PACKAGE}

The result of the study showed that bond construction had $100 \%$ adoption, nursery $99 \%$, puddling

\begin{tabular}{|c|c|c|c|c|c|c|}
\hline Acronym & Description & Measurement & Min & Max & Mean & $S D$ \\
\hline \multicolumn{7}{|c|}{ Socio economic characteristics } \\
\hline SEX & $\operatorname{sex}$ & male (1) and female (2) & \multicolumn{4}{|c|}{ mostly male } \\
\hline$A G G$ & age & continuous variable in years & 20 & 72 & 48.13 & 12.04 \\
\hline$E D D$ & educational level & $\begin{array}{l}\text { no formal education (1), primary education } \\
(2) \text {, secondary education ( } 3) \text {, and tertiary } \\
\text { education (4). }\end{array}$ & \multicolumn{4}{|c|}{$\begin{array}{c}\text { most of respondents } \\
\text { had no formal education }\end{array}$} \\
\hline HHSIZ & household size & number of persons in the household & 3 & 27 & 14 & \\
\hline$F S Z$ & farm size & continuous variable in hectares & 1 & 50 & 6.02 & 7.17 \\
\hline$Y E I L$ & yield & continuous variable in tones & 4 & 210 & 6.88 & \\
\hline$Y R E X P$ & years of experience & continuous variable in years & 5 & 50 & 25.16 & 12.80 \\
\hline$I N C M^{1)}$ & income & continuous variable in Naira & 80 & 5250 & 786 & \\
\hline \multicolumn{7}{|c|}{ Factors influencing adoption } \\
\hline ATTR & attributes of sawah technology & dummy ( 1 if yes, 0 if no) with 8 items scale & 3 & 8 & 7.73 & \\
\hline PERC & perceptions and values & dummy ( 1 if yes, 0 if no) with 7 items scale & 2 & 7 & 4.86 & \\
\hline PROD & distribution of production factors & dummy ( 1 if yes, 0 if no) with 7 items scale & 3 & 7 & 6.08 & \\
\hline INFO & $\begin{array}{l}\text { access to information and extension } \\
\text { services }\end{array}$ & dummy ( 1 if yes, 0 if no) with 5 items scale & 0 & 5 & 4.80 & \\
\hline POLY & policy/institutional supports & dummy ( 1 if yes, 0 if no) with 6 items scale & 0 & 6 & 4.20 & \\
\hline
\end{tabular}
98\%, flooding 95\%, levelling and smoothening 94\% and power tiller use $88 \%$ adoption. This reveals that

Table 1. Socio-economic characteristics of respondents $(n=300)$

${ }^{1)}$ Score shown are divided by 1000 .

Source: own study. 
sawah technology package has high adoption among the respondents. The high yield from sawah field, the improvement in the rate of tillering of the rice, efficiency of fertilizer usage and effective weeds control may account for the high adoption [FASHOLA et al. 2006]. According to TSUJIMOTO et al. [2009], sawah approach offers low-cost irrigation and water control for rice intensification with sustainable paddy yield of more than $4 \mathrm{t} \cdot \mathrm{ha}^{-1}$ but with improved agronomic practices, such as the System of Rice Intensification (SRI) with the sawah technology, paddy yield can reach more than $10 \mathrm{t} \cdot \mathrm{ha}^{-1}$. As reported by OLADELE and WAKATSUKI [2008], sawah overcomes soil fertility problems through enhancing geological fertilization process and conserves water resources. The high performance multi-functionality of the sawah technology may also contribute to its adoption among the respondents.

Table 2. Level of adoption of sawah technology package $(n=300)$

\begin{tabular}{|l|c|c|}
\hline \multicolumn{1}{|c|}{ Innovation package } & $\begin{array}{c}\text { Number } \\
\text { of adopters }\end{array}$ & $\begin{array}{c}\text { Percentage } \\
\text { of adopters }\end{array}$ \\
\hline Puddling & 300 & 100.00 \\
\hline Flooding & 297 & 99.00 \\
\hline Levelling & 294 & 98.00 \\
\hline Smoothnening & 282 & 94.00 \\
\hline Nursery & 284 & 94.67 \\
\hline Power tiller use & 251 & 83.67 \\
\hline Dyke construction & 58 & 19.33 \\
\hline Bond construction & 172 & 57.33 \\
\hline Fish and sawah production & 61 & 20.33 \\
\hline Cannal construction & 98 & 32.67 \\
\hline Use of sand bags & 114 & 38.00 \\
\hline
\end{tabular}

Source: own study.

\section{RELATIONSHIP BETWEEN ADOPTION AND SOCIO-ECONOMIC VARIABLES}

The result showed that adoption of sawah technology is significantly related to $\operatorname{sex}(\beta=0.022)-$ Table 3. This implies that the sex of the respondents determines their adoption. The adoption of sawah technology is dominated by male farmers which may be the due to strenuous and laborious nature of technology. This may also not be far from the fact the male farmers are decision maker who decided on what is good for the family. In addition, the study area is dominated by muslim and male farmers. It is believed that the females are to be taking care of children while the males source for means of family livelihood. Also, in this part of the country, most women are purdah who doesn't go out of their house.

The age of the farmers $(\beta=-0.049)$ was found to be significantly related to level of adoption. This implies that young farmers adopt sawah than the older ones. Older farmers find it difficult to change from their former way of doing thing for a new method. The younger farmers may be agile and inquisitive, ready to learn new things, wanting to know more, hence increase their level of adoption. Sawah technol- ogy need relatively healthier and stronger younger farmers to adopt than older counterparts because of the requirements for bunding, puddling and transplanting which may be energy demanding.

The result showed that adoption of sawah technology is significantly related to year of experience $(\beta=0.058)$. This implies that the higher the years of experience in rice production, the better for adoption of sawah technology. Farmers who have spent more years on rice production would have known the problems they encounter which sawah technology can solve. They will therefore be in a better position to appreciate sawah technology adoption. Although this may not be in all cases as some with more years of experience may tend to resist change due to the knowledge they believed they have acquired. The result showed that adoption of sawah technology is significantly related to education $(\beta=0.215)$. This implies that the higher the level of education the better for adoption. This is in line with the finding of GHOLAMREZAI and SEPAHVAND [2017] that educational level of farmer affects farmers' attitudes towards participating in Water User Association in western Iran. An improvement in farmers' educational attainment can increase the understanding and probability of agricultural technology adoption.

The study further showed that farm size $(\beta=0.085)$ is significantly related to adoption of sawah technology. This mean that the larger the farm size, the greater the level of adoption. Sawah technology needs a large area of land to accommodate the construction of bunds, canals and drainages for effective water distribution. Yield of sawah rice ( $\beta=2.021$ ) was also found to be significantly related to adoption of sawah technology among the respondents. The result of this study is in agreement with ALI-OLUBANDWA et al. [2010] who reported that adoption is significantly related to yield among farmers. According to WAKATSUKI et al. [2011], sawah systems can sustain paddy yields higher than $4 \mathrm{t} \cdot \mathrm{ha}^{-1}$ through geological fertilization and sustainable paddy yields above $10 \mathrm{t} \cdot \mathrm{ha}^{-1}$ can be achieved with the application of advanced agronomic practices. Income of the farmers $(\beta=2.911)$ had a significant relationship with the adoption among the farmers. This implies

Table 3. Regression between adoption and socio-economic variables $(n=300)$

\begin{tabular}{|l|r|r|r|r|r|}
\hline Variable & $\begin{array}{c}\text { Coefficient } \\
\beta\end{array}$ & $S E$ & $T$ & $P$ & $\begin{array}{c}95 \% \text { conf. } \\
\text { interval }\end{array}$ \\
\hline SEX & 0.022 & 0.001 & 2.780 & 0.006 & 0.003 \\
\hline$A G G$ & -0.049 & -0.009 & -5.280 & 0.000 & -0.031 \\
\hline$E D D$ & 0.215 & 0.078 & 2.750 & 0.006 & 0.061 \\
\hline$F S Z$ & 0.085 & 0.022 & 3.820 & 0.000 & 0.148 \\
\hline$I N C M$ & 2.911 & 7.351 & 3.970 & 0.000 & 1.471 \\
\hline YREXP & 0.058 & 0.020 & 2.860 & 0.005 & 0.097 \\
\hline YEIL & 2.021 & 0.332 & 6.090 & 0.000 & 2.674 \\
\hline Constant & 8.089 & 0.608 & 13.310 & 0.000 & 6.893 \\
\hline
\end{tabular}

Explanations: $S E=$ standard error, $n=300=$ number of observations; Prob $>F=0.0000 ; R^{2}=0.3487$; Adj $R^{2}=0.3331$.

Source: own study. 
that farmers with higher income are able to adopt sawah technology. Higher income of farmers will allow them to acquire inputs like the power tiller, fertilizer, seeds and labour which are capital intensive.

\section{RELATIONSHIP BETWEEN ADOPTION AND PREDICTOR VARIABLES}

The study revealed that attributes of sawah technology $(\beta=0.265)$ was significantly related to adoption. These attributes include high yield, disease and pest management, fertilizer management, weed control, water management and tillering. SALL et al. [2000] reported that yield and tillering capacity were considered most important attributes of rice variety among farmers in Senegal. The site-specific farmers' personal irrigated sawah system development offers low cost irrigation and water control for rice intensification, with sustainable paddy yield of 4-6 th ha ${ }^{-1}$. Lowland sawah systems can sustainably produce about $2 \mathrm{t} \cdot \mathrm{ha}^{-1}$ paddy without any chemical fertilizer application [HIROSE, WAKATSUKI 2002; WAKATSUKI et al. 2009]. In addition, lowland sawah systems can support rice cultivation continuously for decades, centuries or more without any fallow period.

There was also a significant relationship between adoption and farmers' perceptions of sawah technology $(\beta=0.399)$. SALL et al. [2000] also reported that farmers' perceptions of technology-specific characteristics significantly influence adoption decisions relating to improved rice varieties. The development and management of sawah system require local farmers to be self-motivated with positive perception. Perception is viewed to contain goals including those achieved and those yet to be achieved and hence, is looked upon as a guiding concept of behaviour and/or decisionmaking [GENGAJE 1996].

As shown in Table 4, access to information and extension services $(\beta=0.428)$ is significantly related to adoption. Sustainability of agricultural production depends largely on actions of the farmers and their ability to make decisions given the level of knowledge and information available to them. Access to information as well as capacity to understand the technical aspects related to the modern technology may influence crop production decisions [RAHMAN 2002]. The innovation-decision process is not passive;

Table 4. Regression between adoption and predictor variable $(n=300)$

\begin{tabular}{|l|c|c|c|c|c|}
\hline Variable & $\begin{array}{c}\text { Coefficient } \\
\beta\end{array}$ & $S E$ & $T$ & $P$ & $\begin{array}{c}95 \% \text { conf. } \\
\text { interval }\end{array}$ \\
\hline POLY & 0.032 & 0.218 & 0.150 & 0.885 & 0.397 \\
\hline PERC & 0.399 & 0.399 & 1.190 & 0.015 & 0.261 \\
\hline PROD & 0.643 & 0.093 & 6.940 & 0.000 & 0.461 \\
\hline INFO & 0.428 & 0.157 & 2.720 & 0.007 & 0.737 \\
\hline ATTR & 0.265 & 0.068 & 3.890 & 0.000 & 0.131 \\
\hline Constant & 2.265 & 2.360 & 0.960 & 0.000 & 0.019 \\
\hline
\end{tabular}

Explanations as in in Table 3; $R^{2}=0.3221$.

Source: own study. it is basically an information-seeking and information-processing activity in which the individual is motivated to reduce uncertainty about the advantages and disadvantages of an innovation [ROGERS 2003]. An important pre-requisite for the adoption and diffusion of an innovation within a social system is the effective communication of information relating to the innovation involved [SHARMA et al. 2007].

The result showed a significant relationship between adoption of sawah technology and production factors $(\beta=0.643)$. The production factors identified include land tenure and land availability, labour availability, availability of input and access to credit. As reported by ALARIMA et al. [2016], accessibility to land with a secured tenancy is a prerequisite for sawah development. Sawah design requires the construction of permanent structures such as bund, canals and basins that require land that is secured for a long period of time. Labour and input are very important factors required for effective adoption of sawah technology. In addition, ADEMILUYI et al. [2008] found out that availability of power tiller, a multipurpose hand tractor designed primarily for rotary tilling and other operations on the farm will enhance the adoption of sawah technology among the farmers. FEDER et al. [1985] also found out that credit availability determined farmers adoption of a technology. KOHLI and SINGH [1997] found that inputs played a large role in the rapid adoption. That is, making the technological innovations and their complementary inputs more easily and cheaply available allowed the technology to diffuse faster and increase the rate of adoption.

\section{CONCLUSIONS}

The study showed that adoption of sawah technology package was high among the respondents. The adoption of sawah technology was influenced by socio-economic characteristics which include sex, age, educational level, farm size, yield and income of the farmers. The study also showed that the attributes of sawah, production factors, information and extension and perception of respondent toward sawah technology influenced adoption. This clearly provides an opportunity to design and strategize sawah dissemination process in other parts of Nigeria bearing in mind the findings of this study. Improvement of those factors that significantly affect adoption of sawah technology is recommended. The study specifically recommended that

1. Unemployed youth in the country should be motivated to venture into sawah rice production rather than looking for white colar jobs. They will be able to serve as successor farmers to the ageing farmers.

2. Interest free loan should be provided to sawah farmers to enable them buy the necessary inputs especially the power tiller needed for the puddling of sawah field. 
3. State governments (who are the custodian of land) should provide land dedicated for rice production with secured tenancy for the farmers to serve as incentive since sawah required a large expanse of land with secured tenancy which will enable the farmers break even on their investment in sawah structures.

4. Government and other non-governmental agencies should help in creating awareness and information to rice farmers on the benefits and qualities of sawah technology especially on soil fertility improvement.

\section{Acknowledgements}

Studies were financed by Japan Society for the Promotion of Science (Grant-in-Aid Scientific Research No. 24405047 and No. 19002001).

\section{REFERENCES}

Ademiluyi Y.S., Oladele I.O., Wakatsuki T. 2008. Socio-economic factors affecting power tiller use among sawah farmers in Bida, Nigeria. Journal of Food, Agriculture and Environment. Vol. 6. Iss. 3-4 p. 387-390.

AkPOKODJE G., LANCON F., Olaf E. 2002. Nigeria's rice policy and development: A review. Final draft. Abidjan. West African Rice Development Association pp. 8.

Alarima C.I., Aromolaran A.K., Masunaga T., WaKATSUKI T. 2016. Effect of land tenure on the adoption of sawah rice production system in Nigeria. Journal of Extension Systems. Vol. 32. Iss. 2 p. 69-84.

Alarima C.I., Kolawole A., Sodiya C.I., Oladele O.I., MASUNAGA T., WAKATSUKI, T. 2011. Factors affecting the adoption of sawah technology system of rice production in Nigeria. Journal of Food, Agriculture and Environment. Vol. 9. Iss. 3-4 p. 177-183.

Ali-Olubandwa A.M., Odero-Wanga D., Kathuri N.J., SHIVOGA W.A. 2010. Adoption of improved maize production practices among small scale farmers in the agricultural reform era: The case of western province of Kenya. Journal of International Agricultural and Extension Education. Vol. 17. Iss. 1 p. 21-30.

Balasubramanian V., Sie M., Hijmans R. J., Otsuka K. 2007. Increasing rice production in sub-Saharan Africa: Challenges and opportunities. Advance Agronomy. Vol. 94 p. 55-133.

BuRi M.M., MASUnAGa T., WAKATSUKI T. 2000. Sulfur and zinc levels as limiting factors to rice production in West Africa lowlands. Geoderma. Vol. 94 p. 23-42.

Doss D.C. 2006. Analysing technology adoption: Challenges and limitations of micro-studies. Agricultural Economics. Vol. 34 p. 207-219.

Fashola O.O., Oladele O.I., Aliyu J., Wakatsuki T. 2006. Dissemination of sawah rice technology to farmers cultivating inland valleys in Nigeria. [4th Australasia Pacific Extension Conference]. [6-8.03.2006 Beechworth, Victoria].

Feder G., Just R.E., Zilberman D. 1985. Adoption of agricultural innovations in developing countries: A survey. Economic Development and Cultural Change. Vol. 33 p. 255-295.

GENGAJE R.K. 1996. Rural development in villagers' perception: analytical approach to strengthening the interface between people and officials - the case study of a district in India. [Unpublished PhD Dissertation]. [11. 10. 2017 Bangkok. Asian Institute of Technology].
Gholamrezai S., SePahVAnd F. 2017. Farmers' participation in Water User Association in western Iran. Journal of Water and Land Development. No. 35 p. 49-56. DOI 10.1515/jwld-2017-0067.

HirOSE S., WAKATSUKI T. 2002. Restoration of inland valley ecosystems in West Africa. $1^{\text {st }}$ ed. Tokyo. Norin Tokei Kyokai. ISBN 4-541-02920-0 pp. 573.

IRRI 2001 Rice web [online] Los Baños. International Rice Research Institute. [Access 11. 10. 2017]. Available at: http://oryza.com/africa/nigeria/index.shtml

KoHLI I., SINGH N. 1997. Exports and growth: Critical minimum effort and diminishing returns. Journal of Development Economics. Vol. 30 p. 391-400.

Ogundele O.O., OKORUWA V.O. 2006. Technical efficiency differentials in rice production technologies in Nigeria [online]. African Economic Research Consortium Research Paper. No. 154. [Access 11.10.2017]. Available at: http://opendocs.ids.ac.uk/opendocs/handle/ $123456789 / 2584$

Oladele O.I., WaKATSUKi T. 2008. Social factors affecting wetlands utilization for agriculture in Nigeria - A case study of sawah rice production. Rice Science. Vol. 15. Iss. 2 p. $150-152$.

PCU 2002. Crop area yield survey (CAY). Project Coordinating UNIT. Abuja. Federal Ministry of Agriculture and Rural Development.

RAHMAN S. 2002. Technological change and food production sustainability in Bangladesh agriculture. Asian Profile. Vol. 30 p. 233-246.

RoGERS E.M. 2003. Diffusion of innovations. $5^{\text {th }}$ ed. New York. Free Press. ISBN 978-0-7432-2209-9 pp. 551.

Sall S., Norman A.D., Featherstone B.A.M. 2000. Quantitative assessment of improved rice variety adoption: The farmer's perspectives. Agricultural Systems. Vol. 66 p. 129-144.

Sharma R., Grover V., Chaturvedi S. 2007. Health-risk behaviors related to road safety among adolescent students. Indian Journal Medical Sciences. Vol. 61 p. 656662.

TSUjimoto Y., Horie T., RANDriamihary H., Shiraiwa T., HommaA K. 2009. Soil management: The key factors for higher productivity in the fields utilizing the system of rice intensification in the central highland of Madagascar. Agricultural Systems. Vol. 100 p. 61-71.

WAKATSUKI T., BURI M.M. 2008. General concept of sawah system. In: The sawah system of rice production. Ed. M.M. Buri, R.N. Issaka, T. Wakatsuki. CSIR-Soil Research Institute, Kumasi, Ghana. pp. 6-27.

Wakatsuki T., Buri M.M., OBAlum S.E., BAM R., Oladele O.I., Ademiluyi S.Y., Azogu I.I. 2011. Farmers' personal irrigated sawah systems to realize the green revolution and Africa's rice potential. [ $1^{\text {st }}$ International Conference on Rice for Food, Market, and Development (rice-Africa)]. [3-5.03. 2011 Abuja, Nigeria].

Wakatsuki T., Buri M.M., Oladele O.I. 2009. West African green revolution by sawah eco-technology and the creation of African SATOYAMA systems. Kyoto Working Papers on Area Studies No. 63 (G-COE Series 61). Center for Southeast Asian Studies, Kyoto, Japan. ISBN 9784901668637 pp. 30.

WARDA 2003. Strategy for rice sector revitalization in Nigeria. Abidjan. West Africa Rice Development Association pp. 14.

WARDA, NISER 2001. Report of the stakeholders Workshop. 8-9.11.2001 Ibadan, Nigeria. West Africa Rice Development Association, Nigerian Institute of Social and Economic Research pp. 16. 
Wikipedia undated. Kebbi State [online]. Wikipedia the free encyclopedia. [Access 27.06.2017]. Available at: https://en.wikipedia.org/wiki/Kebbi_State

Williams S.K.T., Fenley J.M., WiLliams C.E. 1984. A manual for agricultural extension workers in Nigeria. Ibadan. Les Shyraden. ISBN 9782318043 pp. 130.
Wortman C., Kirungu B. 1999. Adoption of legumes for soil improvement and forage by smallholder farmers in Africa. In: Working with Farmers: The key to adoption of forage technologies. Ed. W. Stur, P. Horne, J. Hacker, P. Kerridge. Proceedings of International Workshop. 12-15.10.1999 Cagayan de Oro City, Philippines. ACIAR Proceedings No. 95 p. 140-148.

\section{Cornelius I. ALARIMA, Joseph M. AWOTUNDE, Comfort O. ADAMU, Dare AKERELE, Tsugiyuki MASUNAGA, Toshiyuki WAKATSUKI}

\section{Zastosowanie eko-technologii sawah w produkcji ryżu przez gospodarstwa rolne w stanie Kebbi w Nigerii}

\section{STRESZCZENIE}

Badano czynniki wpływające na stosowanie technologii sawah w stanie Kebbi w Nigerii. Sawah oznacza wyrównane pola ryżowe otoczone wałami z dopływem i odpływem wody do nawodnień i drenażu. Stosując sprawdzony uprzednio schemat wywiadu, zebrano dane od 300 rolników stosujących technologię sawah na badanym obszarze. Zebrane dane analizowano statystycznie z użyciem programu STATA. Wyniki wskazują, że ankietowani to w większości żonaci mężczyźni bez formalnego wykształcenia. Średnia wieku wynosiła 48,13 lat, liczba osób w gospodarstwie - 14, wielkość gospodarstwa - od 1 do 50 ha ze średnią 4,70 ha, a średni plon wynosił $6,88 \mathrm{t} \cdot \mathrm{ha}^{-1}$. Wyniki dowiodły również, że konstrukcje wzmacniające stosowane w tej technologii zyskały 100\% akceptacji respondentów, szkółki - 99\%, uszczelnianie gliną - 98\%, zalewanie - 95\%, wyrównywanie pól $-94 \%$, a stosowanie mechanicznych kultywatorów $-88 \%$. Na akceptację technologii sawah wpływały czynniki społeczno-ekonomiczne takie jak płeć, wiek, poziom wykształcenia, wielkość gospodarstwa, plon i przychody rolników. Badania dowiodły również, że właściwości sawah, czynniki produkcyjne, informacja i percepcja technologii przez respondentów wpływały na jej akceptację. Podsumowując, eko-technologia sawah jest szeroko akceptowana przez rolników w stanie Kebbi. Zaleca się, aby czynniki wpływające na akceptację technologii zostały uwzględnione przy poszerzaniu tej technologii na inne stany Nigerii. Pożądane jest również polepszanie tych czynników, które kształtują pozytywny odbiór technologii sawah przez rolników.

Słowa kluczowe: akceptacja, czynniki, Nigeria, stan Kebbi, technologia sawah 